\title{
Perbedaan $\mathrm{pH}$, Viskositas dan Volume Saliva setelah Berkumur dengan Obat Kumur Sintetik yang Mengandung Chlorhexidine dan Larutan Propolis pada Anak Usia 11-12 Tahun
}

\section{(Difference of $\mathrm{pH}$, Viscosity and Volume Saliva after Gargling with Synthetic Mouthwash Containing of Chlorhexidine and Propolis Solution for 11-12 Years Old Children)}

\author{
Shinta Dinyanti ${ }^{1}$, Roedy Budirahardjo ${ }^{2}$, Raditya Nugroho ${ }^{3}$ \\ ${ }^{1}$ Fakultas Kedokteran Gigi Universitas Jember \\ ${ }^{2}$ Bagian Pedodonsia Fakultas Kedokteran Gigi Universitas Jember \\ ${ }^{3}$ Bagian Konservasi Gigi Fakultas Kedokteran Gigi Universitas \\ JIn. Kalimantan 37, Jember 68121 \\ e-mail: shinta_dinyanti@yahoo.co.id
}

\begin{abstract}
Dental caries is a process that begins with dissolution of enamel causing damage to the dental component by several factors, such as saliva. The occurrence of diseases in the oral cavity is prevented by the use of synthetic mouthwash containing chlorhexidie, but the using of synthetic compounds causes mutagenic effects on the oral cavity, so it needs alternative by using natural ingredients that have antibacterial power and smaller side effects. The purpose of the study was to investigate the difference of $\mathrm{pH}$, viscosity and volume saliva after gargling with synthetic mouthwash containing of chlorhexidine and propolis solution for children age 11-12 years in Pondok Pesantren Nurul Islam Antirogo Jember. This study used pra-experimental One Shoot Case Study with total sampling in Pondok pesantren Nurul Islam Antirogo Jember. As many 25 students were recruited for the study. The result showed that after gargling with propolis solution can be increase of $\mathrm{pH}$ saliva, decrease of viscosity saliva and increase of volume saliva for children age 11-12 years in Pondok Pesantren Nurul Islam Antirogo Jember.
\end{abstract}

Keywords : Saliva, Chlorhexidine, Propolis Solution.

\begin{abstract}
Abstrak
Karies gigi adalah suatu proses yang dimulai dengan larutnya enamel yang menyebabkan kerusakan pada komponen gigi yang disebabkan oleh beberapa faktor, salah satunya adalah saliva. Untuk mengatasi masalah terjadinya penyakit di rongga mulut, diantaranya adalah dengan penggunaan obat kumur sintetik yang mengandung chlorhexidie, akan tetapi penggunaan senyawa sintetis menyebabkan efek mutagenik pada rongga mulut. Alternatif lain yaitu dengan menggunakan bahan alami yang memiliki daya antibakteri dan efek samping yang lebih kecil. Tujuan penelitian ini untuk mengetahui perbedaan $\mathrm{pH}$, viskositas dan volume saliva setelah berkumur dengan obat kumur sintetis yang mengandung chlorhexidine dan larutan propolis untuk anak usia 11-12 tahun di Pondok Pesantren Nurul Islam Antirogo Jember. Penelitian ini menggunakan pra-eksperimental One Shoot Case Study dengan metode total sampling di Pondok pesantren Nurul Islam Jember sebanyak 25 orang. Hasil penelitian menunjukkan bahwa setelah berkumur dengan larutan propolis dapat meningkatkan $\mathrm{pH}$ saliva, penurunan viskositas saliva dan peningkatan volume saliva pada anak usia 11-12 tahun di Pondok Pesantren Nurul Islam Antirogo Jember.
\end{abstract}

Kata kunci: Saliva, Chlorhexidine, Larutan Propolis 


\section{Pendahuluan}

Prevalensi karies pada anak di Indonesia terus meningkat [1]. Menurut data terakhir Riset Kesehatan Dasar (RISKESDAS) tahun 2013, indeks DMF-T meningkat seiring dengan bertambahnya usia yaitu sebesar 1,4 pada kelompok umur 12 tahun, kemudian 1,5 pada umur 15 tahun dan 1,6 pada umur 18 tahun. Usia 11 hingga 12 tahun anak lebih muda diajak berkomunikasi dan diperkirakan semua gigi permanen telah erupsi kecuali gigi molar tiga, serta usia tersebut merupakan kelompok yang mudah dijangkau oleh usaha kesehatan gigi sekolah [2]. Usia 12 tahun sampai usia 15 tahun karies gigi mengalami peningkatan yang besar. Kemudian pada usia 45 tahun aktivitas karies mulai menurun, tetapi pada usia ini penyakit periodontal mulai aktif [3].

Kelompok yang rentan terhadap karies gigi adalah anak-anak usia sekolah. Pondok pesantren merupakan lembaga pendidikan formal berbasis religiusitas dengan peserta didik atau santri yang tinggal di dalamnya. Pondok pesantren dihadapkan pada sejumlah tata tertib yang wajib untuk dipenuhi dan berbeda dengan sekolah umumnya. Pola konsumsi makanan para santri menggambarkan perilaku makan para santri di pesantren. Di pesantren biasanya santri tinggal di asrama atau pondok dan jauh dari orang tua. Pola konsumsi makanan santri biasanya sama karena sekelompak orang hidup dalam lingkungan dan tata tertib yang sama [4].

Karies gigi atau gigi berlubang ditandai oleh rusaknya email dan dentin yang disebabkan oleh aktivitas metabolisme bakteri dalam plak yang menyebabkan terjadinya demineralisasi akibat interaksi antar produkproduk mikroorganisme, saliva dan bagianbagian yang berasal dari makanan [5]. Makanan manis dan lengket mengandung karbohidrat yang merupakan sumber energi utama bagi bakteri mulut dan secara langsung terlibat dalam penurunan $\mathrm{pH}$, peningkatan viskositas dan penurunan volume saliva [6].

Saliva menjadi salah satu faktor yang mempunyai pengaruh besar terhadap keparahan karies gigi [6]. Saliva dengan $\mathrm{pH}$ kritis yaitu 5,5 dapat mengakibatkan disolusi hidroksiapatit yang disebut demineralisasi pada gigi. Produksi saliva yang mengalami gangguan dapat mempengaruhi viskositas dan $\mathrm{pH}$ saliva, sehingga dapat menyebabkan volume dan fungsi saliva menjadi terganggu [7].

Metode yang telah diterapkan untuk mengatasi masalah terjadinya penyakit di rongga mulut, diantaranya adalah dengan penggunaan obat kumur sintetik. Bahan antimikroba yang digunakan dalam obat kumur adalah chlorhexidine [8]. Meski efektif untuk menghambat pembentukan plak, sebaiknya obat kumur tidak boleh digunakan secara terusmenerus dalam jangka waktu yang panjang. Beberapa penelitian menunjukkan adanya gangguan keseimbangan jumlah mikroflora normal mulut akibat penggunaan obat kumur secara terus-menerus [9]. Penggunaan senyawa sintetis memiliki efek mutagenik pada mulut. Oleh sebab itu, Alternatif obat kumur untuk menggantikan adalah dengan bahan alami yang memiliki daya antibakteri dengan efek samping yang lebih kecil [10].

Propolis merupakan bahan alamiah yang dihasilkan oleh lebah dan mempunyai banyak manfaat terutama dalam bidang kesehatan dan saat ini digunakan secara luas sebagai obat [11]. Propolis merupakan getah yang dikumpulkan oleh lebah dimana getah tanaman tersebut kemudian dicampur dengan enzim yang terdapat dalam kelenjar ludah yaitu enzim invertase. Guna enzim ini adalah memecah sukrosa menjadi glukosa dan fruktosa [12].

Propolis memiliki daya antibakteri karena memiliki kandungan flavonoid. Senyawa flavonoid berfungsi sebagai antibakteri dengan cara membentuk senyawa kompleks terhadap protein di luar sel yang mengganggu kekuatan membrane sel bakteri. Kelebihan propolis sebagai antibiotik alami dibandingkan dengan bahan sintetik adalah lebih aman serta efek samping yang kecil [11].

\section{Metode Penelitian}

Jenis penelitian ini merupakan jenis penelitian eksperimental laboratoris dengan rancangan pra-experimental: One Shoot Case Study. Pengambilan sampel dilakukan di Pondok Pesantren Nurul Islam Antirogo Jember yang dilakukan pada bulan Oktober 2018. Pengambilan sampel menggunakan teknik total sampling dan di dapatkan sampel sebanyak 25 siswa untuk laki-laki dan perempuan dengan ketentuan berumur 11-12 tahun, tidak mengalami gangguan sekresi saliva, keadaan rongga mulut karies dan non karies serta mengisi informed consent yang telah disetujui oleh orang tua.

Alat-alat yang dibutuhkan dalam penelitian ini adalah $\mathrm{pH}$ meter merk Hanna, viscositometer ostwald, pot obat, gelas kumur, beaker glass, 
gelas ukur, stopwatch, tisu, pengaduk, alat tulis, masker dan sarung tangan. Bahan yang dibutuhkan adalah obat kumur sintetik dengan merk minosep dengan komposisi chlorhexidine gluconate $0,1 \%$, propolis dengan merk melia propolis, kertas label dan aquadest steril.

Subjek diminta untuk mengisi surat persetujuan (informed consent) yang telah disetujui oleh orang tua. Kemudian pada hari pertama, subjek diminta untuk berkumur dengan menggunakan aquadest steril selama 30 detik dan dibuang. Lalu pada menit ke 10, subjek diminta untuk berkumur dengan menggunakan chlorhexidine sebanyak $30 \mathrm{ml}$ dan dikumur selama 30 detik. Kemudian subjek diminta untuk mengumpulkan saliva dengan metode passive drool pada pot obat selama 10 menit.

Hari kedua subjek diminta untuk berkumur dengan menggunakan aquadet steril selama 30 detik dan dibuang. Lalu pada menit ke 10, subjek diminta untuk berkumur dengan menggunakan propolis yang diteteskan pada quadest steril sebanyak 15 tetes dengan takaran $30 \mathrm{ml}$ dan dikumur selama 30 detik. ubjek diminta untuk mengumpulkan saliva dengan metode passive drool pada pot obat selama 10 menit. Lalu dilakukan pengukuran $\mathrm{pH}$, viskositas dan volume saliva.

\section{Hasil}

Perhitungan $\mathrm{pH}$, viskositas dan volume saliva dilakukan di laboratorium mikrobiologi Fakultas Kedokteran Gigi Universitas Jember dengan jumlah sampel yang didapatkan adalah 25 sampel. Hasil perhitungan nilai rata-rata, standart deviasi, persentase dan analsa data menggunakan uji wilcoxon $\mathrm{pH}$, viskositas dan volume saliva pada siswa laki-laki dan perempuan ditampilkan pada Tabel 1, Tabel 2 dan Tabel 3.

Tabel 1 Nilai Rata-rata, Standart Deviasi, Persentase Peningkatan $\mathrm{pH}$ Saliva dan Analisa Data pada Subjek Laki laki dan Perempuan

\begin{tabular}{|c|c|c|c|c|c|}
\hline \multirow{2}{*}{$\mathrm{N}$} & \multirow{2}{*}{$\begin{array}{c}\text { Jenis } \\
\text { Kelam } \\
\text {-in }\end{array}$} & $\begin{array}{c}\text { Chlorhe- } \\
\text { xidine }\end{array}$ & $\begin{array}{l}\text { Larutan } \\
\text { Propolis }\end{array}$ & \multirow{2}{*}{$\begin{array}{l}\text { Pers- } \\
\text { entase }\end{array}$} & \multirow{2}{*}{$\begin{array}{c}\text { Anali- } \\
\text { sa } \\
\text { Data }\end{array}$} \\
\hline & & $\begin{array}{c}\text { Mean } \pm \\
\text { SD }\end{array}$ & $\begin{array}{c}\text { Mean } \pm \\
\text { SD }\end{array}$ & & \\
\hline 9 & $\begin{array}{l}\text { Pere- } \\
\text { mpuan }\end{array}$ & $\begin{array}{l}7,9 \pm \\
0,44\end{array}$ & $\begin{array}{l}8,2 \pm \\
0,17\end{array}$ & $3,7 \%$ & 0,000 \\
\hline 16 & $\begin{array}{l}\text { Laki - } \\
\text { laki }\end{array}$ & $\begin{array}{c}7,7 \pm \\
0,50\end{array}$ & $\begin{array}{l}8,2 \pm \\
0,22 \\
\end{array}$ & $6,4 \%$ & 0,000 \\
\hline
\end{tabular}

Keterangan :

$\mathrm{N}$ : Jumlah Subjek

SD : Standart Deviasi

Mean : Rata-rata
Tabel 1 menunjukan nilai rata - rata, standart deviasi persentase peningkatan $\mathrm{pH}$ saliva dan analisa data dengan uji wilcoxon saat berkumur dengan chlorhexidine dan larutan propolis pada subjek laki-laki dan perempuan. Pada subjek perempuan didapatkan nilai ratarata $\mathrm{pH}$ saliva sebesar 7,9 pada saat berkumur dengan chlorhexidine dan mengalami peningkatan $3,7 \%$ menjadi 8,2 setelah berkumur dengan larutan propolis. Pada subjek laki-laki didapatkan nilai rata-rata $\mathrm{pH}$ saliva sebesar 7,7 pada saat berkumur dengan chlorhexidine dan mengalami peningkatan sebesar $6,4 \%$ menjadi 8,2 setelah berkumur dengan larutan propolis.

Tabel 2 Nilai Rata-rata, Standart Deviasi, Persentase Penurunan Viskositas Saliva dan Analisa Data pada Subjek Laki laki dan Perempuan

\begin{tabular}{|c|c|c|c|c|c|}
\hline \multirow{2}{*}{$\mathrm{N}$} & \multirow{2}{*}{$\begin{array}{c}\text { Jenis } \\
\text { Kelam } \\
\text {-in }\end{array}$} & $\begin{array}{c}\text { Chlorhe- } \\
\text { xidine }\end{array}$ & $\begin{array}{l}\text { Larutan } \\
\text { Propolis }\end{array}$ & \multirow{2}{*}{$\begin{array}{l}\text { Pers- } \\
\text { entase }\end{array}$} & \multirow{2}{*}{$\begin{array}{c}\text { Anali- } \\
\text { sa } \\
\text { Data }\end{array}$} \\
\hline & & $\begin{array}{c}\text { Mean } \pm \\
\text { SD }\end{array}$ & $\begin{array}{c}\text { Mean } \pm \\
\text { SD }\end{array}$ & & \\
\hline 9 & $\begin{array}{c}\text { Pere- } \\
\text { mpuan }\end{array}$ & $\begin{array}{c}4,98 \pm \\
0,17\end{array}$ & $\begin{array}{c}3,43 \pm \\
1,03\end{array}$ & $31,1 \%$ & 0,000 \\
\hline 16 & $\begin{array}{c}\text { Laki - } \\
\text { laki }\end{array}$ & $\begin{array}{c}3,94 \pm \\
1,56\end{array}$ & $\begin{array}{c}3,17 \pm \\
0,86\end{array}$ & $19,5 \%$ & 0,000 \\
\hline
\end{tabular}

Keterangan :

$\begin{array}{ll}\mathrm{N} & \text { : Jumlah Subjek } \\ \mathrm{SD} & \text { : Standart Deviasi } \\ \text { Mean } & \text { : Rata-rata } \\ \text { Viskositas saliva dalam satuan cP (centipoises) }\end{array}$

Tabel 2 menunjukan nilai rata-rata, standart deviasi persentase penurunan viskositas saliva dan analisa data dengan uji wilcoxon saat berkumur dengan chlorhexidine dan larutan propolis pada subjek laki-laki dan perempuan. Pada subjek perempuan didapatkan nilai rata-rata viskositas saliva sebesar 4,98 cP pada saat berkumur dengan chlorhexidine dan mengalami penurunan $31,1 \%$ menjadi $3,43 \mathrm{cP}$ setelah berkumur dengan larutan propolis. Pada subjek laki-laki didapatkan nilai rata-rata viskositas saliva sebesar 3,94 cP pada saat berkumur dengan chlorhexidine dan mengalami penurunan sebesar $19,5 \%$ menjadi 3,17 cP setelah berkumur dengan larutan propolis. 
Tabel 3 Nilai Rata-rata, Standart Deviasi, Persentase Peningkatan Volume Saliva dan Analisa Data pada Subjek Laki laki dan Perempuan

\begin{tabular}{|c|c|c|c|c|c|}
\hline \multirow{2}{*}{$\mathrm{N}$} & \multirow{2}{*}{$\begin{array}{l}\text { Jenis } \\
\text { Kelam } \\
\text {-in }\end{array}$} & $\begin{array}{c}\text { Chlorhe- } \\
\text { xidine }\end{array}$ & $\begin{array}{l}\text { Larutan } \\
\text { Propolis }\end{array}$ & \multirow{2}{*}{$\begin{array}{l}\text { Pers- } \\
\text { entase }\end{array}$} & \multirow{2}{*}{$\begin{array}{c}\text { Anali- } \\
\text { sa } \\
\text { Data }\end{array}$} \\
\hline & & $\begin{array}{l}\text { Mean } \pm \\
\text { SD }\end{array}$ & $\begin{array}{c}\text { Mean } \pm \\
\text { SD }\end{array}$ & & \\
\hline 9 & $\begin{array}{l}\text { Perem } \\
\text {-puan }\end{array}$ & $\begin{array}{c}6,58 \pm \\
2,12\end{array}$ & $\begin{array}{c}7,01 \pm \\
2,50\end{array}$ & $6,5 \%$ & 0,000 \\
\hline 16 & $\begin{array}{l}\text { Laki - } \\
\text { laki }\end{array}$ & $\begin{array}{c}6,59 \pm \\
2,15\end{array}$ & $\begin{array}{c}8,62 \pm \\
3,30\end{array}$ & $30,8 \%$ & 0,000 \\
\hline
\end{tabular}

Keterangan :

$\mathrm{N}$ : Jumlah Subjek

SD : Standart Deviasi

Mean : Rata-rata

Volume saliva dalam satuan $\mathrm{ml}$ (mililiter)

Tabel 3 menunjukan nilai rata-rata, standart deviasi persentase peningkatan volume saliva dan analisa data uji wilcoxon saat berkumur dengan chlorhexidine dan larutan propolis pada subjek laki-laki dan perempuan. Pada subjek perempuan didapatkan nilai ratarata volume saliva sebesar $6,58 \mathrm{ml}$ pada saat berkumur dengan chlorhexidine dan mengalami peningkatan $6,5 \%$ menjadi $7,01 \mathrm{ml}$ setelah berkumur dengan larutan propolis. Subjek lakilaki didapatkan nilai rata-rata volume saliva sebesar $6,59 \mathrm{ml}$ pada saat berkumur dengan chlorhexidine dan mengalami peningkatan sebesar $30,8 \%$ menjadi $8,62 \mathrm{ml}$ setelah berkumur dengan larutan propolis. Peningkatan $\mathrm{pH}$ saliva, penurunan viskositas saliva dan peningkatan volume saliva dapat dilihat pada grafik pada Gambar 1.

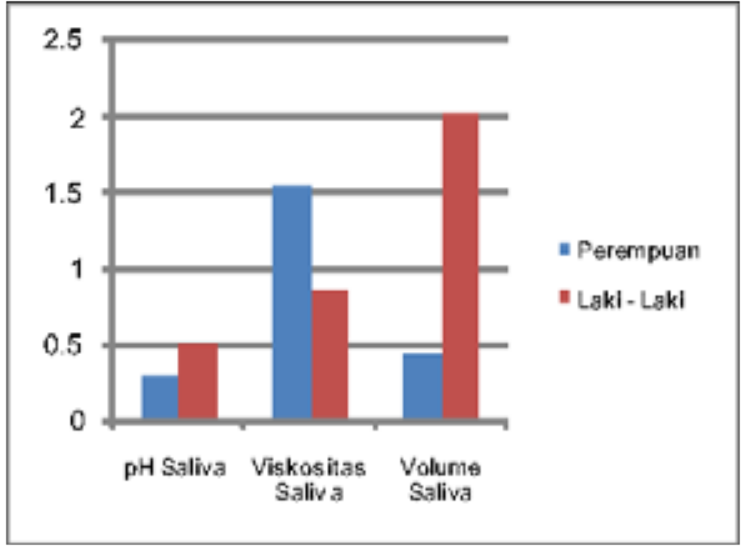

Gambar 1 Grafik Selisih Peningkatan dan Penurunan $\mathrm{pH}$, Volume dan Viskositas Saliva Setelah Berkumur dengan Larutan Propolis pada Subjek Laki-laki dan Perempuan

Gambar 1 menunjukkan selisih peningkatan dan penurunan $\mathrm{pH}$, viskositas dan volume saliva setelah berkumur dengan chlorhexidine dan larutan propolis pada subjek laki-laki dan perempuan. Peningkatan $\mathrm{pH}$ saliva pada subjek laki-laki sebesar 0,5 lebih tinggi daripada subjek perempuan yaitu 0,3, penurunan viskositas saliva pada subjek laki-laki sebesar $0,77 \mathrm{cP}$ lebih rendah daripada subjek perempuan yaitu $1,55 \mathrm{cP}$ dan peningkatan volume saliva pada subjek laki-laki sebesar 2,03 $\mathrm{ml}$ lebih tinggi daripada subjek perempuan yaitu $0,43 \mathrm{ml}$.

\section{Pembahasan}

Hasil penelitian yang telah dilakukan pada $\mathrm{pH}$ saliva setelah berkumur dengan menggunakan chlorhexidine dan larutan propolis baik pada subjek perempuan dan laki-laki menunjukkan adanya suatu perbedaan. Subjek perempuan yang berkumur dengan chlorhexidine nilai dari rata-ratanya adalah 7,9 dan naik menjadi 8,2 setelah berkumur dengan larutan propolis sehingga persentase kenaikan pada subjek perempuan mencapai $3,7 \%$. Subjek laki-laki yang berkumur dengan chlorhexidine nilai dari rata-ratanya adalah 7,7 dan naik menjadi 8,2 setelah berkumur dengan larutan propolis sehingga persentase kenaikan pada subjek laki-laki mencapai $6,4 \%$. Analisa data statistik yaitu menggunakan uji Wilcoxon didapatkan hasil $p=0,000$ yang artinya ada perbedaan yang bermakna karena nilai $p<0,05$ pada seluruh subjek yang berkumur dengan menggunakan chlorhexidine dan larutan propolis.

Flavonoid yang terkandung didalam propolis memiliki daya antibakteri sehingga dapat meningkatkan $\mathrm{pH}$ saliva serta propolis mengandung rasa yang pahit, beraroma seperti 'cairan' kayu dan karena diambil langsung dari sarang lebah. Rasa pahit propolis menunjukkan jika propolis memiliki suasana basa dan dapat menetralkan asam. Propolis memiliki suasana basa sehingga dapat mempengaruhi tingkat keasaman $\mathrm{pH}$ saliva [13].

Larutan propolis menjadikan keadaan rongga mulut basa yang dapat mengakibatkan ketidakseimbangan mikroflora normal di rongga mulut [14]. Apabila dibandingkan dengan larutan chlorhexidine dalam meningkatkan $\mathrm{pH}$ saliva, masih lebih baik chlorhexidine karena selain memilki sifat antiseptik, chlorhexidine mampu meningkatkan $\mathrm{pH}$ saliva dengan angka $\mathrm{pH}$ yaitu 7,9 untuk subjek perempuan dan 7,7 untuk subjek laki-laki, sehingga dalam rentan $\mathrm{pH} 7,7$ dan 7,9 keseimbangan flora normal di rongga 
mulut tetap terjaga. Saliva sebagai sistem penyangga untuk menjaga $\mathrm{pH}$ optimal mulut, yaitu $\mathrm{pH}$ yang cenderung basa [15].

Hasil penelitian pada volume saliva pada subjek laki-laki dan perempuan terdapat adanya suatu perbedaan. Subjek perempuan yang berkumur dengan chlorhexidine nilai dari rata-ratanya adalah $6,58 \mathrm{ml}$ dan naik menjadi 7,01 setelah berkumur dengan larutan propolis sehingga persentase kenaikan pada subjek perempuan mencapai $6,5 \%$. Subjek laki-laki yang berkumur dengan chlorhexidine nilai dari rata-ratanya adalah $6,59 \mathrm{ml}$ dan naik menjadi $8,62 \mathrm{ml}$ setelah berkumur dengan larutan propolis sehingga persentase kenaikan pada subjek laki-laki mencapai $30,8 \%$. Analisa data statistik yaitu menggunakan uji Wilcoxon didapatkan hasil $p=0,000$ yang artinya ada perbedaan yang signifikan karena nilai $p<0,05$ pada seluruh subjek yang berkumur dengan menggunakan chlorhexidine dan larutan propolis.

Peningkatan volume saliva dapat mencegah dari karies gigi [16]. Peningkatan volume saliva pada subjek dipengaruhi oleh propolis karena propolis memiliki rasa yang lebih pahit dibandingkan dengan chlorhexidine. Rasa pahit sendiri selain merangsang dari $\mathrm{pH}$ saliva yang menjadikan suasanya rongga mulut menjadi basa, dapat mengakibatkan sekresi saliva menjadi lebih banyak. Subjek yang berkumur dengan chlorhexidine, volume saliva yang dihasilkan tidak sebanyak subjek yang berkumur dengan larutan propolis dikarenakan rasa dari chlorhexidine yang cenderung kesat sehingga sekresi saliva yang dihasilkan lebih sedikit [17].

Hasil penelitian yang telah dilakukan pada viskositas saliva setelah berkumur dengan menggunakan chlorhexidine dan larutan propolis baik pada subjek perempuan dan laki laki menunjukkan adanya suatu perbedaan. Subjek perempuan setelah berkumur dengan larutan propolis turun dari 4,98 cP menjadi $3,43 \mathrm{cP}$ sehingga persentase penurunan mencapai $31,1 \%$ subjek laki-laki turun dari 3,94 cP menjadi $3,17 \mathrm{cP}$ sehingga persentase penurunan mencapai $19,5 \%$. analisa data statistik yaitu menggunakan uji Wilcoxon didapatkan hasil $p=$ 0,000 yang artinya ada perbedaan yang signifikan karena nilai $p<0,05$ pada seluruh subjek yang berkumur dengan menggunakan chlorhexidine dan larutan propolis.

Penurunan angka viskositas saliva akan mengakibatkan viskositas saliva menjadi encer dan menyebabkan efek self cleansing di dalam rongga mulut menjadi lebih baik [18]. Viskositas saliva mengalami penurunan diakibatkan karena peningkatan laju aliran saliva yang menyebabkan sekresi saliva meningkat sehingga terjadi peningkatan volume dan penurunan dari viskositas saliva [19].

\section{Simpulan dan Saran}

Nilai rata-rata $\mathrm{pH}$ saliva meningkat setelah berkumur dengan menggunakan propolis, nilai rata-rata viskositas saliva menurun setelah berkumur dengan menggunakan propolis dan nilai rata-rata volume saliva meningkat setelah berkumur dengan menggunakan propolis, sehingga dapat ditarik kesimpulan bahwa terdapat perbedaan yang bermakna antara $\mathrm{pH}$, viskositas dan volume saliva pada subjek laki-laki maupun perempuan setelah berkumur dengan chlorhexidine dan larutan propolis.

Larutan propolis dapat diaplikasikan menjadi obat kumur alami pada santri di Pondok Pesantren Nurul Islam Antirogo Jember karena berasal dari bahan alami. Perlu dilakukan penelitian lebih lanjut mengenai hubungan antara volume, viskositas dan $\mathrm{pH}$ saliva pada anak usia 11 - 12 tahun setelah berkumur dengan larutan propolis dan formulasi aplikasi larutan propolis sebagai sediaan obat kumur yang baik, yaitu terkait konsentrasi larutan dan frekuensi penggunaanya.

\section{Daftar Pustaka}

[1] Sutjipto RW, Herawati, Kuntari S. Prevalensi early childhood caries dan severe early childhood caries pada anak prasekolah di Gunung Anyar Surabaya. Dental Journal. 2014; 47(4): 187-189.

[2] Trihono. Riset Kesehatan Dasar. Badan Penelitian dan Pengembangan Kesehatan Kementerian Kesehatan RI. 2013.

[3] Kiswaluyo. Hubungan karies gigi dengan umur dan jenis kelamin siswa sekolah dasar di wilayah kerja puskesmas Kaliwates dan puskesmas Wuluhan Kabupaten Jember. Stomatognatic (J.K.G. Unej). 2010; 7(1): 26-30.

[4] Farida R. Hubungan pola jajan terhadap indeks DMF-T pada santriwati SMP Pondok Pesantren Pembangunan Sumur Bandung, Kecamatan Cililin Kabupaten Bandung Barat. Skripsi: Bandung. Politeknik Kesehatan Bandung. 2017. 
[5] Ramayanti S, Purnakarya I. Peran makanan terhadap kejadian karies gigi. Jurnal Kesehatan Masyarakat. 2013; 7(2): 89-93.

[6] Suratri MAL, Jovina AA, Indirawati TN. 2017. Pengaruh $(\mathrm{pH})$ saliva terhadap terjadinya karies gigi pada anak usia prasekolah. Buletin Penelitian Kesehatan. 45(4): 241- 248.

[7] Margeretha I. Kajian senyawa bioaktif propolis Trigona spp. sebagai agen anti karies melalui pendekatan analisis kimia dipandu dengan bioassay. Jakarta: Universitas Indonesia. 2012.

[8] Sinaredi BR, Pradopo S, Wibowo TB. Daya antibakteri obat kumur chlorhexidine, povidone iodine, fluoride suplementasi zinc terhadap Streptococcus mutans dan Porphyoromonas gingivalis. Majalah Kedokteran Gigi. 2014; 47(4): 211-214.

[9] Sallika NS. 2010. Serba - Serbi Kesehatan Perempuan: Apa yang Perlu Kamu Tahu tentang Tubuhmu?. Jakarta: Bukuné. 2010.

[10] Khan S, Hasan S, Khan, U. Asad. 2015. Genotoxic Effects of Chlorhexidine Mouthwash on Buccal Epithelial Cells. International Journal of Dentistry and Oral Health. 2015; 10(2): 1-6.

[11] Kurniawati D. Uji aktivitas antibakteri propolis Trigona spp. Asal Bukit Tinggi pada tikus putih Sprague-Dawle. J. Prog. Kim. Si. 2011; 1(1): 25-31.

[12] Saputri AF. Perbedaan efektifitas antibakteri antara klorheksidin 2\% dan propolis 25\% terhadap Enterococcus faecali. Skripsi. Makassar: Fakultas
Kedokteran Gigi Universitas Hasanuddin. 2013.

[13] Sariyem, Sadimin, Yuwana RP. Pengaruh mengkonsumsi larutan propolis terhadap $\mathrm{pH}$ saliva. Jurnal Kesehatan Gigi. 2014; 1(1): 47-52.

[14] Hadiati S. Kandidiasis pseudomembran pada lidah akibat pemakaian obat kumur heksetidin serta penatalaksanaannya. Majalah Kedokteran Gigi. 2011; 18(2): 178181.

[15] Rahayu YC, Kurniawati A. Cairan Rongga Mulut. Yogyakarta: Pustaka Panasea. 2018.

[16] Savita A, Sungkar S, Chrismirina S. Perbandingan laju aliran saliva sebelum dan sesudah mengunyah permen karet nonxylitol dan xylitol pada anak usia 10 12 tahun. Journal Caninus Dentistry. 2017; 2(2): $65-70$.

[17] Rawung F, Wuisan J, Leman MA. Pengaruh obat kumur beralkohol terhadap laju aliran saliva dan $\mathrm{pH}$ saliva. Jurnal eGiGi. 2017; 5(2): 125-129.

[18] Wirawan E, Puspita S. 2017. Hubungan pH saliva dan kemampuan buffer dengan DMF-T dan def-t pada periode gigi bercampur anak usia 6-12 tahun. Insisiva Dental Journal. 2017; 6(1): 25-30.

[19] Kusumayani P, Harijanti K, Hernawan I. Perbedaan flow saliva pada wanita menopause sebelum dan sesudah mengunyah permen karet yang mengandung xylitol. Oral Medicine Dental Journal. 2011; 3(1): $24-29$. 